\title{
Research of Tianjin Port Explosion under the Lack of Power List
}

\author{
Dongyang $\mathrm{He}$ \\ College of Literature Law \& Economics \\ Wuhan University of Science \& Technology \\ Wuhan, China, 430065
}

\begin{abstract}
Along with the pace of the reform of the political system in China, the operation of the government's public power is gradually rising to the policy level. Although in recent years, the power list system has been launched in the country, but there are still a lot of loopholes in the public safety issues, many administrative officials did not realize the significance of the list of powers. This paper analyzes the direct and indirect causes of the Tianjin port explosion, points out the problems in the background of the power list and the urgency of the implementation of the list of power system on the basis of it.
\end{abstract}

Keywords—power boundary; power restriction; supervision

\section{INTRODUCTION}

The power-list system refers to the clearly specified public power and legal way of clearly the public power implemented by government departments at all levels, and making the power list public. Combined with the current situation of the local governments, the list of power has not been fully implemented. Behind a series of public security incidents represented by the Tianjin Port Explosion, the reason is that the government's public power is unclear, the power operation lacks supervision, and the administrative staff abuses of authority.

Therefore, the list of power is not only an accidental policy recommendation, but also an inevitable reform mechanism. Only if public power and the corresponding duties and responsibilities of government are clearly stated, it's possible to effectively protect the citizens' most basic rights of life and health, and achieve "clean" government.

\section{THE DEVELOPMENT AND IMPLEMENTATION OF THE POWER-LIST SYSTEM}

\section{A. The Power-list System Put Forward}

In the "law of the spirit", Montesquieu pointed that "all those who have power are easy to abuse of power" [1], because the power of their own legal maintenance and management authority on the authority of the executive than the ordinary People's choices and opportunities. In the power of social collisions, the public power of the government has distinctive characteristics in source, essence and application form. From the source, our constitution stipulates: "All power belongs to the people", which shows that the people is the owner of public power, while the government is only the executive organ appointed from public power. The source of power determines the nature of power that is to serve the public interests of the people. As the dominant of local economy, politics, culture and other fields, the government masters public power which includes the power of production factors and resource allocation, which is the base of government's macroeconomic regulation and control, but also the operation of the market, the lifeblood of enterprise development.

The "monopoly" characteristic of public power determines that it will lead to war of justice and desire for money in closed mode. The power indulged and abused of resulted in more and more social problems such as prevalent broken law' s enterprises, unfair competition of markets, resources utilized inefficiently, the destruction of the ecological environment, and the lack of public security. The government urgently needs a system to regulate how many fields the government can be involved in. And people urgently need to see the power given to government administrators truly serve the people, rather than secretly operate for personal gain. It is under this social reality that the power-list system came into being.

\section{B. The Meaning and Purpose of the Power-list System}

The power-list system, as the name suggests, explicitly lists the public power actually held by government departments at all levels, and specifies in detail the correct process and legal means for exercising power and making them public. The implementation of the list of powers extends from the central to the local. Any government departments who perform their functions, excise their power must be in accordance with the laws and regulations of the list. And any power does not belong to the scope of the list, the executive authorities shall not do so.

The most fundamental purpose of the implementation of the power- list system is to protect the public interests of the people, so that people can supervise the power of government, understand the boundaries and dynamic operation of power through Internet and visit to government, which can improve people's rights to know and supervise, in turns to strengthen the constraints of public power. 
Specifically, that is, when the functional departments exist oversight and loss of behavior, and administrative personnel exist vacancy and offside, the people have the power, evidence, and the ability to request the government to go back to the seat, making public power as the basis of civil rights for the existence, so as to safeguard people's lives and property, build a harmonious social environment. The power-list system really exposes the government power to the sun, so that each power to implement and each nonconfidential activities of government can be socially supervised, which effectively become the administrative tool of realization of the interests of the people. [2].

\section{THE DIRECT CAUSE OF TIANJIN PORT EXPLOSION UNDER THE LACK OF POWER LIST}

Xinhua reported that the fire and explosion incidents involved multi-level government departments violation of discipline and dereliction of duty, the specific circumstances are of the table below "Table I".

TABLE I. TIANJIN PoRT EXPLOSIVE RESPONSIBILITY TABLE

\begin{tabular}{|c|c|c|c|c|}
\hline $\begin{array}{l}\text { Department } \backslash \\
\text { units }\end{array}$ & characteristic & responsibility & Irregularities & Treatment measures \\
\hline $\begin{array}{l}\text { Tianjin } \\
\text { Communications } \\
\text { and } \\
\text { Transportation } \\
\text { Commission }\end{array}$ & $\begin{array}{l}\text { Administration } \\
\text { Department } \\
\text { Hazardous } \\
\text { Chemicals } \\
\text { Tianjin Port }\end{array}$ & $\begin{array}{l}\text { Dangerous chemicals } \\
\text { business is subject to } \\
\text { approval, supervision } \\
\text { and other duties }\end{array}$ & $\begin{array}{l}\text { Not seriously perform their duties, illegal issuance of } \\
\text { business licenses }\end{array}$ & $\begin{array}{l}\text { In order to suspend the } \\
\text { crime of dereliction of } \\
\text { duty, according to the } \\
\text { law for investigation and } \\
\text { take criminal coercive } \\
\text { measures }\end{array}$ \\
\hline $\begin{array}{l}\text { Tianjin } \\
\text { Production } \\
\text { Safety } \\
\text { Supervision and } \\
\text { Administration } \\
\text { Bureau }\end{array}$ & $\begin{array}{lr}\text { Safety } & \text { supervision } \\
\text { and management } \\
\text { departments }\end{array}$ & $\begin{array}{l}\text { On the area of } \\
\text { enterprises, especially } \\
\text { hazardous chemicals } \\
\text { business enterprises } \\
\text { have a regulatory } \\
\text { responsibility for the } \\
\text { safe production }\end{array}$ & $\begin{array}{l}\text { Poor supervision, the existence of the company's security } \\
\text { risks and illegal business problems did not promptly check } \\
\text { found and investigated according to law }\end{array}$ & ditto \\
\hline $\begin{array}{l}\text { Binhai New } \\
\text { Area Safety } \\
\text { Production } \\
\text { Supervision and } \\
\text { Administration } \\
\text { Bureau }\end{array}$ & $\begin{array}{lr}\text { Safety } & \text { supervision } \\
\text { and management } \\
\text { departments }\end{array}$ & $\begin{array}{l}\text { On the area of } \\
\text { enterprises, especially } \\
\text { hazardous chemicals } \\
\text { business enterprises } \\
\text { have a regulatory } \\
\text { responsibility for the } \\
\text { safe production }\end{array}$ & $\begin{array}{l}\text { Poor supervision, the existence of the company's security } \\
\text { risks and illegal business problems did not promptly check } \\
\text { found and investigated according to law }\end{array}$ & ditto \\
\hline $\begin{array}{lr}\text { Binhai } & \text { New } \\
\text { Area } & \text { Planning } \\
\text { and } & \text { Land } \\
\text { Resources } & \\
\text { Administration }\end{array}$ & $\begin{array}{l}\text { Planning and } \\
\text { management of } \\
\text { various construction } \\
\text { projects }\end{array}$ & \begin{tabular}{lr}
\multicolumn{2}{l}{ On the jurisdiction of } \\
enterprises & operating \\
hazardous & chemicals \\
storage & business \\
planning & approval \\
duties &
\end{tabular} & $\begin{array}{l}\text { Not strictly reviewed Ruichai company operating hazardous } \\
\text { chemicals storage space violation of safe distance, illegal } \\
\text { approval of hazardous chemicals warehousing business } \\
\text { planning }\end{array}$ & ditto \\
\hline $\begin{array}{l}\text { Tianjin Newport } \\
\text { Customs }\end{array}$ & & & $\begin{array}{l}\text { Not responsible for the supervision and control of import } \\
\text { and export of hazardous chemicals, oversight of the daily } \\
\text { supervision of the company, the illegal activities of } \\
\text { hazardous chemicals is not promptly discovered and } \\
\text { investigated; to do not have the qualification of the company } \\
\text { opened up green access channel, indulge in Ruihai company } \\
\text { Illegal business activities }\end{array}$ & ditto \\
\hline $\begin{array}{l}\text { Department of } \\
\text { Water Transport, } \\
\text { Ministry of } \\
\text { Transport }\end{array}$ & & & $\begin{array}{l}\text { Illegal to exercise their powers to help do not meet the } \\
\text { safety requirements of the company through the safety } \\
\text { assessment of the Swiss company }\end{array}$ & $\begin{array}{l}\text { To suspicion of abuse of } \\
\text { power, according to the } \\
\text { law on file for } \\
\text { investigation and take } \\
\text { criminal measures }\end{array}$ \\
\hline
\end{tabular}

It is not difficult to see from the above table that the explosion in Tianjin Port is not only an incident of public safety, but also a potential consequence of the unclear boundaries of government power and lack of effective control of power. It is precisely because that the Tianjin administrative organs at all levels did not establish a clear power boundary, the executive power is kept in a closed cage to run, which makes some administrative staff abuse of power or let power, contrary to the interests of the people, do not work at the core Power operation concept. In view of this, the following direct cause of the explosion in Tianjin Port will be summarized from three aspects of the absence of the power list.
${ }^{\text {a. }}$ Source: http://baike.haosou.com/doc/10878842-1 1404593.

\section{A. Oversight of Local Planning}

According to state regulations, the work safety supervision and management departments have the responsibility to develop and strictly supervise the safe distance of hazardous chemicals. According to the "Conditions and Technical Requirements for Operating Enterprises of Dangerous Chemicals", large and mediumsized dangerous chemicals warehouses should be located far away from urban areas and Residential areas and should be at least 1,000 meters away from the surrounding public buildings, transport routes, industrial and mining enterprises. 
In the planning of Tianjin Port, Tianjin Ruihai company's hazardous chemicals warehouse is only 600 meters away from the nearest residential area, $1 \mathrm{~km}$ around the warehouse there distribute the highway, the Tianjin-Hong Kong light rail and other important infrastructure, even is only 1,500 meters away from the national supercomputing Tianhe, Tianjin Center, this industrial zone and residential planning serious violate scientific proof without a reasonable budge and ignore the safety and health of the people.

\section{B. The Government Let the Power Free Making Tianjin Port Group Work Alone}

According to the survey, in accordance with the "Tianjin Dongjiang Free Trade Port Management Provisions", the Tianjin Port Group under the Ministry of Planning and Construction is solely responsible for the planning and construction within Tianjin Port . For all project development and landing implementation, it should firstly get approval of the Tianjin Group Planning and Construction Department, then it will be sent To Binhai District Planning Bureau for approval.

The unreasonable "safe distance" planning in the harbor area is mainly based on the "Code for Fire Protection of Building Design", which stipulates that the distance between the warehouse and the building with the highest risk level is $12 \mathrm{~m}$ to $30 \mathrm{~m}$, Important public buildings should not be less than 50 meters. This means that no matter how dangerous the goods, as long as its warehousing is more than 50 meters away from the surrounding buildings, they are in line with the approval conditions, which is clearly no scientific assessment of risk, such a "safe distance" is extremely insecure.

Binhai New Area management model is completely reversed, the municipal government let free public power, gives authority to the leading enterprises in the decentralization of administrative examination, so that make Hong Kong harbor dominant. Government 's inaction, laziness and self - planning of enterprises are blasphemy against public power and irresponsible to the public.

\section{The Administrative Personnel Abuse Their Power to Indulge in Irregularities}

Ruihai company explosion of hazardous chemicals is due to a number of administrative departments of abuse of administrative power . First of all, Tianjin Transportation Committee works as the sector authorities management for dangerous chemicals in Tianjin Port, it illegal issued operating permits and had a poor supervision of illegal activities; Secondly, the Tianjin Municipal Administration of Work Safety and Binhai New Area security Production supervision and Management Bureau did not find the existence of the company's security risks of illegal business problems, they did not investigated and dealt with it according to laws; Finally, the Binhai New Area Planning and Land Resources Bureau responsible personnel aware of the company Ruichai dangerous chemicals storage sites in violation of security Distance regulations, not strictly examine the checks, illegal approval of the company's hazardous chemicals storage business planning.

The abuse of power by the administrative staff caused the deviation of the executive power, the offside, resulting in illegal enterprises, illegal business activities become more rampant, in violation of the principle of fair competition in the market, not only illegal activities under the banner of "reasonable approval" flag openly exist To the legitimate interests of other industries, long-term existence, only to lose the confidence of the executive authority of the executive power of the loss of trust.

\section{THE DEEP CAUSES OF THE EXPLOSION OF TIANJIN PORT UNDER THE LACK OF POWER LIST}

\section{A. Local Government only Pursues Economy Development}

As a result of rating, evaluation, title, some local government officials only pursue local economy growth, gradually marriage power and interest .They use improper means to stimulate or encourage all enterprise behavior that can bring real economic growth. On the basis that the administrative power is not open, some of government's investment is contrary to the public, which will make GDP growth only, but ignore if the transferred enterprises can benefit the local people and improve social services. They lack public safety awareness, just because this, Tianjin Port Group considered financing ways and wanted to get commercial interests quickly, so they made the so-called "depth" development, to build factories within a safe distance. The relevant safety supervision departments of Tianjin not only failed to fulfill the duty of investigating and punishing according to law, but also used their own power to open the way for their approval of customs clearance, which resulted in collusion between the government and enterprises, departments and departments collusion reality. In view of this, the government's one-sided pursuit of economic growth is actually an endogenous power, and the power is unknown, the responsibility is unclear so as to promote its direct harm to the catalyst.

\section{B. The Power List Is Numerous and the Boundary Is Unknown}

At present, the functions of the government are complex. It is not scientific to categorize the various kinds of power according to different departments. On the one hand, it causes power duplication, on the other hand, it makes the power disperse excessively, which reduce the government's efficiency and positive autonomy. Tianjin Port was originally under the management of the Ministry of Transport, and later transformed into enterprises, the right to appoint and remove personnel, business guidance to the Ministry of Communications, Tianjin, Tianjin, traffic management commissioned. Tianjin Port power scattered to the various departments of unbalanced coordination, the entire operating mechanism is loosely, resulting in weak regulation and poor investigate .

There are a number of similar problems regarded to the list of powers that are currently published. Most of the 
functional power has a large concept of power, the implementation process is difficult to understand for the citizens. The publication of the power list is often limited to combing or merging the powers owned by the government departments, then to find out the corresponding legal basis for re-legalizing these powers, in fact, this is called "rectify power". Moreover, it is difficult to sort out the power of the government by the departments under the administrative system, and to some extent, it is to "comb their own power". It can be said that both "athletes" and "referees" are to ensure their own power fair without drying out.

\section{The Close Connection between Government and Enterprises Stimulates Money Trading}

Proper handling of the relationship between the government and enterprises is to ensure fair operation of the market. An important factor is healthy competition. Tianjin Municipal Government gives the administrative examination and approval and self-planning rights to the Tianjin Port Group, resulting in a port of Tianjin, Hong Kong dominance. As an independent kingdom, which is the embodiment of government and corporate bad relations. The government holds the resources and the enterprise holds the capital. On the one hand, the government can not become a "strong government" and compete for enterprise market dominance. Also, the government can not be too close with the enterprise, especially to give priority to the rights of enterprises, which will result in resource mismatch, excessive concentration and waste. So that companies take advantage of the situation regardless of the laws and regulations to rent-seeking behavior, create opportunities for money trading.

\section{Lack of Effective Supervision of Public Power}

1) Internal oversight issues: Misuse of power is largely due to the imperfections in the system of internal administrative oversight of the government and the failure to monitor failure. In Tianjin Port bombing incident, the performance of dereliction of duty and abuses by Tianjin government officials is also the result of the ineffective administrative supervision of Tianjin government, which reflects the lack of effective supervision, and other selfrestraint within the government administrative system, checks and balances of the self-monitoring system. There is no real-time control of the overall situation of government governance.

2) Social supervision issues: Firstly, it's the lack of citizen supervision. Chairman Mao once said, "Let the people to supervise the government". The people as the public naturally have the right to supervision and the right to know. Tianjin Port after the explosion of the incident, Tianjin Port was once out of the Tianjin municipal government management, as the "independent kingdom", with independent planning and construction departments and safety supervision department, who is "athlete" and "referee" two duty, which reflects the Tianjin municipal government has not fulfilled its duties to the jurisdiction, lacked effective management responsibility and management measures, and reflected the social reality of Tianjin people's ignorance and inaction on government activities. Under the current administrative system, the people do not know exactly what powers the government has in the end, what powers have been exercised, what duties and responsibilities have not been fulfilled, and have no way to protect their rights and promote the government to become the owners of power. Obedience, in essence, distorts the meaning of administrative power, in essence, the government corruption, black-box manipulation.

Secondly, the sense of social public opinion is weak. The public can use a variety of mass media to form public opinion to the executive authorities and their activities to implement supervision, which is constitutionally given the rights of the public. Through the television, Internet, newspapers, publications and other carriers, citizens have the right to freedom to reveal administrative errors, correcting dereliction of duty, improve transparency. But at present, our citizens have not yet formed a strong sense of public opinion, or "not related to others, hanging high", or to avoid political "sensitive" issues, fearing of getting into trouble, more attention to entertainment news ignoring the social administrative issues. In short, the community did not give full play to freedom of the press and freedom of speech, public opinion, awareness of the need to be strengthened.

\section{E. Weak Legal Control, Accountability System Is Not Perfect}

Public power should not only accept the people's supervision from the form, but also on the means to accept the supervision of laws and regulations. In the theory of modern administrative rule of law, the principle of legality is a basic principle. It requires the executive authorities to exercise public power when the state must have a legal basis, that is, according to law. At present, Some government departments ignore the legal regulations of private rights, or is not a mistake, not punishment or punishment. That all have contributed to the dark powers of breeding. The weakening of the mandatory law, also relaxes the social regulation [7]. In response to the slogan of national rule of law, government power should be placed in the cage of laws and regulations, as Minister of Finance Lou Jiwei said, with the law to the public power to run the red line, mine areas, to ensure that government departments in strict accordance with statutory responsibilities, Authority, the right to exercise legal procedures, at any time not to engage in privileges, not abuse of powers for illegal administrative acts to take tough legal measures.

\section{THE URGENCY OF THE IMPLEMENTATION OF THE POWER LIST SYSTEM}

\section{A. Safeguard the Basic Rights and Interests of Citizens, and Return to the Government}

The important purpose of the people to give the government public power is to protect the people's life and property, establish a harmonious and orderly social 
environment, and safeguard the most basic legitimate rights and interests of citizens.

Under the background of unknown public power and lack of effective control, the public safety crisis represented by Tianjin Port explosion occurred at high frequency, gas leakage, dangerous building collapses, industrial sewage quotation, bribery, and so on. People as a broad object of the crisis, directly and indirectly paid a heavy price, even the most basic life and health safety. From a social point of view, the outbreak of each public crisis to the public environment has brought irreversible damage, especially the serious pollution of the ecological environment. Abuse of power by the government to chase short-term capital gains, if sustained, will only destroy the environment in which human beings depend, not to mention economic development.

Society is in the intensification of people's public rights and public power contradiction of the moment, if the power of the government to make a difference legitimate to serve the people. That will make people gradually lose confidence in the government and can not coordinate the sustainable development of society. At this level, the implementation of the power list is imminent.

\section{B. Promote Government Performance as the Government to Build Effective}

The current government corruption cases are endless, causing widespread concern at home and abroad, seriously affecting the government's reputation and image. In the final analysis, this also comes from the overlapping and closed operation of public power, mainly in the vertical functional departments and horizontal institutions. First, the central and local government decentralization have not been clearly stipulated in the Constitution and the law, the division of labor is not clear so that the two coordination policy imbalances, indecisive, must not do, inefficient; Second, Local functional departments internal institutions, conflicts between departments, they use their respective power to get more interests for themselves[8]. These two aspects cause administrative laziness, so interests with the positive administration, no interest on the negative. These behaviors reduce government performance.

The power list system display the central and local authorities and departments between the power and power to run the process in black and white. For the central and local: the local government management work within the administrative work of the administrative area, but matters related to national sovereignty, finance, tax, foreign exchange and other matters related to national economic lifeline and cross-regional national affairs should be dealt with by the central government management. For the internal local government, departmental administrators should strictly obey rules, clarify their respective duty, fulfill the obligation, put an end to some departments about restless hand to other departments, offside the ruling behavior. At the same time, strengthen the provincial cities and counties up and down three levels of linkage, arrange for decentralization issues convergence work. Effectively and efficiently solve the problem of cross-duplication of power to ensure that the administrative act in a tight and orderly manner to ensure close coordination between the various departments, help to improve administrative efficiency, to prevent the Government in the performance of their duties or to drag the administration.

\section{A Clear Relationship between the Government and the Market}

The implementation of the power list system provides a resource information platform for the market. The focus of the comprehensive and deepening reform is the economic structural reform. The core of the reform is to "make the market play a decisive role in the allocation of resources and better play the role of the government". To do this, we must deal with the relationship between the government and the market, fully and correctly implement government functions. This includes two tasks: Firstly, the government release the power; Secondly, the government manage the tube of things in place.

The publication of the power list will help to promote the government and the market to discuss on which one should control the core issues, to form a consensus, so as to build an autonomous market economy system. The power of the list system can reduce or regulate the government's administrative examination and approval behavior, which help to stimulate the economic mainstay of the entrepreneurial innovation and the release of the inherent vitality of the market. From the market process point of view, the administrative examination and approval system of the greatest harm to society is that it binds the economic freedom which may combat or hinder entrepreneurial spirit. Especially in the rapid progress of science and technology time, the complex administrative examination and approval procedures will lead entrepreneurs to non-productive activities or even rely on rent-seeking to obtain profits, choking entrepreneurial innovation entrepreneurial power. On the one hand, the power list system makes the government department clear that "the law can not be authorized", it implements the negative list management of market access. This will further liberalize the economic, provide a predictable market environment and incentives for enterprises to freely enter the market, and to publicize the spirit of entrepreneurs, stimulate market vitality.

\section{CONCLUSION}

The implementation of China's power list system is the inevitable trend of China's political reform, which is conducive to the reform of administrative examination and approval system and the implementation of decentralization. China's government managers must be clearly aware of the power given by the people, all government activities should be "serving the people" for the purpose. In order to better carry out government leadership, we should establish a correct concept of power. In addition, the power list is not only a documentary document, its development process and implementation process must be strictly defined, truly "return the power to the people", accept the supervision of the general public, accept the laws and regulations to promote the rational allocation of public resources, public 
security and effective protection, so that the interests of the people to be multi-meet.

\section{REFERENCES}

[1] Wang Jie. On the eve of the development of China's rights list system problems and countermeasures [D]. Wuhan University Master of Public Administration thesis. 2014 (14).

[2] Liu Xuebin. On the implementation of the power list system [J]. Leadership Science Forum, 2015 (1): 2 7.

[3] Jia Yuan, Jin Yamei China's implementation of the power list of the feasibility analysis [J]. Journal of Puyang Vocational and Technical College .2014 (5).

[4] Li Kecheng. Decomposition of the "number one" power [J]. South Windshield, 2013 (26).

[5] Yuan Hao. Look forward to the "power list" of the introduction [J]. Party and Government Forum, 2014 (1).

[6] Cheng Shouyan. From "power list" to "responsibility list" - thinking on the division of authority of government functions [J] .Jiangsu Technology Teachers College, 2011,17 (3).

[7] Lou Yun. Economic Analysis Framework and Policy Suggestions on Anti-Corruption - On the First Power List of Mayors in China [J]. Economic Forum, 2006 (8).

[8] Lin Xiaowen. A Study on the Legal Effect of Local Government Power List [J] .Politics and Law, 2015 (7).

[9] Shen Haiping. The power list can not be transposed over the law [J], academia, 2015 (1). 